\title{
The Influence of Health Promotion on the Healthy Lifestyle of College Students
}

\author{
Yuepeng Sun ${ }^{1, a,{ }^{*},}$ Yu Su ${ }^{1, b}$ and Yifei Zhai ${ }^{2, c}$ \\ ${ }^{1}$ Department of Physical Education, Dalian Maritime University, Dalian, Liaoning, China, \\ ${ }^{2}$ Department of Physical Education, Nanjing University, Nanjing, Jiangsu, China. \\ a452176981@qq.com, b1760902161@qq.com, c29931761@qq.com
}

Keywords: Health promotion, Lifestyle, Seafaring undergraduate

\begin{abstract}
Since 1986, the world health organization (WHO) has introduced the concept of "health promotion", which has attracted much attention. Nowadays, due to the particularity of the study environment of seafaring college students, many of their mental health problems are not conducive to forming a complete personality. This study mainly USES literature review to discuss the psychological problems of college students. Concluded that half militarization management and lack of girls is the main cause of affecting navigation classes of college students' mental health and put forward from the courses in humanities classes or lectures, men and women to participate in the activities, giving play to the role of psychological counselling agencies and open students like elective course from four aspects to build the way of health promotion.
\end{abstract}

\section{Introduction}

Total length of $32000 \mathrm{~km}$ coastline in China, about 470 square kilometers area, the vast, rich Marine resources, combined with the frequent international trade, the navigational class talent demand is great, its lucrative salary also became the college entrance examination application selected popular major. However, some of the psychological problems arising from the enrollment of Marine college students are not conducive to the formation of the complete personality. Therefore, this paper USES the concept of health promotion, namely "encourage people to maintain and improve their health" or "all prompted to healthy behavior and living conditions change of education and the environment support complex" (lu endowment, 2002,9). This is to try to help seafaring students build healthy lifestyles.

\section{Health Promotion is Necessary for The Implementation of Marine College Students}

\subsection{The Lack of Girls Has a Psychological Impact on College Students}

According to our country related relevant scholars of maritime college students in China study found that: "they and their desire to find his beloved girlfriend, but mostly psychological fear his love like a girl" (melchor fai, 2012.10). From world famous psychologist skinner's theory of operation condition reflection, we learn that we human beings any behavior is formed under the constant stimulation, no stimulation or lack of stimulation intensity change, we will gradually decline, existing behavior or even disappear. Therefore, due to lack of communication and communication with girls, seafaring students lack stimulation sources, which will lead to some immature psychological reactions. Lack of female students, however, will also affect navigation class students' study and life, main show is: firstly, the lack of female students into thinking and classroom atmosphere active degree is reduced, affect students' learning motivation; Second, when it comes to difficulties such as bad mood or disorientation, the lack of women's comfort can lead to further negative emotions. Thirdly, the various activities that show the personality, temperament and ability of male students have no female students' appreciation and attention and influence the motivation of male students to participate in activities. 


\subsection{The Influence of Semi-Militarized Management on College Students}

Demilitarized management refers to "internal management carried out by non-military units in the form of military management" (Bi pengjie 2005), "relative to militarization management and general management". No doubt this kind of management professional college students' future work lay a good foundation for discipline, at the same time also can bring many negative effects: first, the school asked the students to participate in the activities, with the dominant, and accounts for a large amount for a long time a lot of their spare time brought great pressure to students, in the case of can't release, will inevitably cause mental health problems. Secondly, college students group is composed by the young adults late teens, energetic, such as not to guide and spread their energy, will make a lot of unexpected violence, it will have a negative impact on college students' life growth.

\section{Health Promotion Is Effective Way for College Students to Implement}

\subsection{Schools Should Offer Courses in Arts and Humanities or Organize Related Lectures.}

Schools should be more humanistic arts courses or lectures, multidirectional students tell their interpersonal knowledge, causes the student to learn the matters that should be paid attention to in the process of interpersonal, such as the methods and techniques, so that we can to a certain extent offset due to the lack of sailing class students bring a lack of interpersonal communication, the greatest degree to help this group through interpersonal crisis.

\subsection{The School Should Organize a Number of Activities Involving Both Men and Women.}

Communication between single male students for a long time, lack of will inevitably brings to the male students in psychological symptoms, make male students psychological emptiness, men and women in common communication platform makes it possible for male students in the psychological comfort, make up the psychological emptiness, prompting sailing class college students' comprehensive development of healthy personality.

\subsection{Schools Should Give Full Play to the Role of Psychological Counselling Agencies.}

School counseling agencies should organize some more mutual help activities, pay more attention to male and female students communication situation, guide the direction of the students' inner need, make it a positive motive demand, they meet difficulty in ease and transfer pressure, the method of improving students' ability to resist frustrations.

\subsection{The School Should Open More Elective Courses That Students Like.}

Students choose elective courses, such as chess, e-sports, fashion sports course, not only can be students learned the knowledge increase in this course to satisfy their thirst for knowledge, but also can put the students' attention to the right place, so that the student's extra energy to vent out, powerful sound personality formation

\section{Summary}

Sailing classes almost don't recruit the girl college students due to the professional requirements, combined with the management adoption half militarization management, affect the normal development of students' psychological cause sailing has deficiencies in such part of the college students' psychological development, it is not healthy, against the world health organization (who) to "healthy" definition. The school should pay more attention to the students' mental health status, provide the platform for the interaction between male and female students, and enrich the interpersonal skills of students. In order to focus on students' health, we should devote more efforts to studying the health promotion model of Marine college students and solve the health problems of seafaring students at an early date.

\section{Acknowledgements}

This research was financially supported by the 12th Five-year Plan of National Science of Education (ELA120409). 


\section{References}

[1]. H.C. Wang, J.H. Lv. Study on the countermeasures of students' physical health promotion intervention in the physical and disadvantaged groups of ordinary universities. Higher agriculture education. Vol. 2 (2013), p. 87-89.

[2]. Z.X. Zhou, Y.B. Xi, L.Y. Zhang, et al. Sports teaching design and experimental study to promote the development of physical health of students. Journal of anhui normal university (natural science edition). Vol. 38 (2015), p. 90-96.

[3]. Y. Tian. Sports activities, physical fitness and health: national fitness and health promotion for 10 years review. Physical science progress. Vol. 45 (2014), p. 243-246.

[4]. L. Yu. Quantitative research on the teaching plan of personalized options aimed at promoting physical health. Journal of wuhan institute of physical education. Vol. 47 (2013), p. 79-86. 